\title{
The Genesis and Development of Church Legislation on Education in the Middle Ages
}

\begin{abstract}
This paper is to present the beginnings and the subsequent development and evolution of church law in the sphere of education from the $4^{\text {th }}$ to the beginning of the $16^{\text {th }}$ century. The roots of the acts of law presented by the Popes, synods and councils were based on the traditions of Roman law, but a variety of reasons from the field of policy, economy and society led to the need to establish a church school system. The aim of the Church was to create an independent school system with its own purposes, different from secular schools.
\end{abstract}

Keywords: church law, education in the Middle Ages

The question of origins of the school-related legislation of the Church must be analysed in the context of cultural, social, economic and religious changes that took place in the Roman Empire in the period from the second half of the third century to the reign of Emperor Constantine the Great. It must be remembered that the first Christian communities that had left the Jewish diaspora remained in ambivalent relations with the Roman state. This is not only about oppression from the administrative apparatus, but also about the attitude to the Roman school by at least some of the Christians. This was also complicated by the fact of embedding the new religion in the literary culture, visible already in the post-apostolic times, which entailed the need for education. The social composition of the first Christian communes, bringing together followers of the new religion promoted by the Apostles and their students, was quite peculiar. They were dominated by poor people, often slaves, who sought to improve their fate in eternal life. Definitely, they included people whose level of education differed from what was represented by the better-off strata of the population ${ }^{1}$. It is worth emphasizing that the attitude of Christian elites to Roman education, or more

\footnotetext{
${ }^{1}$ See: TROCMÉ, É., Pierwsze kroki chrześcijaństwa, Kraków 2004, pp. 44-149.
} 
precisely to school education, referred to as doctrina, was significantly influenced by the period of religious persecution, and it must be kept in mind that, to a large extent, education in the Roman Empire was a responsibility of the state. Teachers were obliged to pass state examinations, which was necessary to obtain a licentia docendi. It can be said that this attitude was characterized by the reluctance and wariness towards the values passed on to students by pagan teachers. This attitude of Christians towards education and learning was undoubtedly influenced by the manifest contained in the Letter to the Corinthians. Epistle to the Corinthians by Saint Paul the Apostle: Where is the wise? Where is the scribe? Where is the disputer of this world? Hath not God made foolish the wisdom of this world? These words were interpreted as an obligation to completely turn away from the achievements of the thought of ancient Greeks and Romans ${ }^{2}$.

However, the anti-school attitude of at least part of Church Fathers and Christian thinkers was counterbalanced by the fact that the new religion was a religion of the Book - the revealed word ${ }^{3}$. Therefore, the spread of the Gospel needed literate people. It is also worth noting that Christianity used writing from the very outset of its history. The exchange of views between individual Christian communities was held in writing, through polemics, dialogues, treatises and letters. Besides, following the Jewish tradition, and initially strongly identifying with it (at least until the end of the first century), Christian communities in Syria, Egypt and Armenia established religious schools ${ }^{4}$.

The essence of the problem, at least when it comes to discussing the problem whether Christian children should attend a Roman school or not, was the link between the GraecoRoman literature and culture and the pagan religion. It posed a moral problem for children, their parents and teachers as well. It should be noted that from the Roman point of view, Christians were godless people, they were even perceived as atheists - like, for example, by Celsus. A Christian teacher, if he wanted to continue his profession, was forced to use texts referring to pagan theology, he could not limit himself to teaching the art of reading and writing only. Tertullian, in his treatise On Idolatry, postulated that teaching activities by Christians be ceased, but confirmed that there was nothing wrong in the fact that Christians learned at school ${ }^{5}$. This consent was not of any greater importance in practice, since in that period baptism applied mostly to adults who had already been educated. Tertullian also stated: How do we repudiate secular studies without which divine teachings cannot be pursued? Learning literature is allowable for believers, rather than teaching; for the principle of learning and of teaching is different ${ }^{6}$.

2 MIREWICZ, J. SJ, Wspóltwórcy $i$ wychowawcy Europy, Kraków 1983, p. 14.

3 More on the topic in: SIMON, M., Cywilizacja wczesnego chrześcijaństwa I-IV w., Warszawa 1979.

${ }^{4}$ MYSZOR, W., Europa - pierwotne chrześcijaństwo. Idee i życie społeczne chrześcijan (II i III wiek), Warszawa 1999/2000, p. 213.

5 Ibidem, p. 213 et seq.

${ }^{6}$ TERTUlian, De idolatria, t. 10, eds. Wasznik, J.H., Winden, J.C.M., Leiden 1987, p. 38 et seq.; Polish translation: MYSZOR, W., Europa-pierwotne chrześcijaństwo, p. 219. 
However, what should be emphasized here, there was a commonly applied practice of educating Christian children in pagan schools, which was not opposed by even the most radical Christian leaders. Their attitude was rooted in the obvious fact that the Roman school was the only source of secular knowledge in the first centuries of Christianity ${ }^{7}$. The Church's new policy towards education and the Roman education system is evident in the work by Saint Basil (ok. 330-379) Address to young men on the right use of Greek literature in which this well-educated hermit pointed to a number of dangers in studying pagan literature, but he treated it primarily as a legacy of the past that should be known ${ }^{8}$. Christian schools were established only where religious communities existed outside the Roman Empire, i.e. in Armenia and Ethiopia, but it was a process that started in the 4th5th centuries.

Concurrently, the process of forming the church legislation took place, which became even faster especially after the proclamation of the so-called Edict of Milan in 313 (nota bene, it was in fact a rescript that in practice was restoring the status of Christians to that from before the persecution), in which Constantine the Great and Licinius announced that Christians had the right to freely profess their religion. This change in the situation of Christian communities was conducive to the creation of certain legal norms that stemmed (though not directly) from the Roman law. It is meaningful that synods were organized during the meetings of municipal councils of the province, and bishops debated in a manner similar to proceedings of the Roman Senate 9 . Moreover, synods and ecumenical councils in the fourth century were convoked by emperors ${ }^{10}$, who presided over them, or with their presence granted a state authorisation for their resolutions. The legislative result of synods was legal norms established by councils and synods, which starting from the end of the fourth century have been called canons ${ }^{11}$. The term canones was used to define all the rules issued by the ecclesiastical authority to regulate the life of the community of the Church and individual believers, without being formal as opposed to leges which were part of the civil law domain ${ }^{12}$.

An important issue worth discussing is the attitude of the Church to the need to create a Church's own school network. It can be generally said that Christianity did not want

7 SKOCZEK, J., Rozwój szkolnictwa w Polsce średniowiecznej, [in:] Historia wychowania, ed. Ł. KURDYBACHA, vol. 1, Warszawa 1965, p. 150.

${ }^{8}$ MIREWICZ, J. SJ, Wspóltwórcy $i$ wychowawcy Europy, Kraków 1983, p. 47.

9 Ibidem, p. 68.

${ }^{10}$ For example: the Synod of Arles of 314, an assembly of bishops "from all the lands of the West" was convoked by Constantine the Great, and presided over by the metropolitan of Arles, Marinius. Emperor Theodosius II issued in November of 430 a decree on the convening of an ecumenical council in Ephesus in June of 431. In 451 the Council of Nicaea, transferred to Chalcedon near Constantinople, was presided over by Emperor Marcian. See: WŁODARSKI, S., Historia papiestwa, vol. 1: do 1073 r., Warszawa 1964, pp. 46-102.

${ }^{11}$ DĘBIŃSKI, A., Kościót i prawo rzymskie, pp. 30-46. See also: HAMPEREK, P., GÓRALSKI, W., Historia źródet nauki prawa kanonicznego, Lublin 1995; SUBERA, J., Historia źródet i nauki prawa kanonicznego, Warszawa 1977.

12 GHIRLANDA, G., Wprowadzenie do prawa kościelnego, Kraków 1996, p. 11. 
to change the ancient school or Roman education, but rather wanted to propose its own model as regards the latter area. The Christian school assimilated the teaching curriculum of the ancient times, and the scope of artes liberales extracted from it was to be an indispensable instrument for understanding the Holy Scriptures. The problem of creating one's own education system was practically non-existent as far as the secular school functioned in a proper way. The situation in this field, still quite good in the times of Saint Augustine ${ }^{13}$ and Saint Jerome, began to rapidly deteriorate in the second half of the fifth century. At that time, the western part of the Roman empire suffered a significant disintegration of the school system, inducing a proper response from the hierarchs. The institutional church faced the need to ensure proper education for candidates for the priesthood ${ }^{14}$. The process of the economic decline of cities began in western Europe, which resulted in their depopulation ${ }^{15}$. At that time, cities were lacking sufficient financial resources to pay teachers and maintain the school infrastructure. The administrative system also collapsed, and the result of the crisis of public administration was a decrease in the demand for people educated in rhetorical art. As a result, there was a significant drop in the number of students, even in those schools that were still operating ${ }^{16}$. This situation posed a threat to the functioning of the Church as an institution using written media and forced its leaders to take adequate remedies.

It seems that the first legal act of the Church regarding education was Canon III of the Council of Chalcedon of 451, referring to clergymen "taking care of minors", which may be a signal of educational projects undertaken at that time, although this does not necessarily mean running schools ${ }^{17}$. Moreover, Canon XVII mentions rural and urban parishes and the rules on establishing them ${ }^{18}$. It seems that that Church authorities in the second half of the 5 th century had to face a new reality in education matters, related to the gradual diminishing of education for the laity. In Gaul, extensive synod statutes originating from around 475 can be noted, which regulated questions of teaching, excluding women from education, even those women referred to as docta et sancta, as well as lay people, while imposing this duty on the clergy ${ }^{19}$. 1993

${ }^{13}$ See ABT, S., Święty Augustyn jako pedagog, Kraków 1930; BROWN, P., Augustyn z Hippony, Warszawa

${ }^{14}$ See BANNIARD, M., Wczesne średniowiecze na Zachodzie, Warszawa 1998, p. 152 et seq.

15 DEVROEY, J.-P., Gospodarka, [in:] Zarys historii Europy. Wczesne średniowiecze od 400 do 1000 r., ed. R. MC KITTERICK, Warszawa 2003, p. 131 et seq. See also HEATHER, P., Upadek cesarstwa rzymskiego, Poznań 2007.

16 WOOD, I., Kultura, [in:] Zarys historii Europy. Wczesneśredniowiecze, p. 204. See also: SMITH, J.M.H., Europa po Rzymie. Historia kulturowa lat 500-1000. Nowe ujęcie, Kraków 2008, p. 27 et seq.

${ }^{17}$ Dokumenty soborów powszechnych, vol. 1, p. 227.

${ }^{18}$ Ibidem, p. 241.

19 Statuta ecclesiae antiqua, [in:] Concilia Galiae A. 314-A. 506, cura et studio C. MUNIER, Corpus Christianorum. Series Latina, vol. CXLVIII, Turnhout 1963, art. 37, p. 172: Mulier, quamuis docta et sancta, uiros in convent docere non praesumat; art. 38, p. 172: Laicus, praesentibus clericis, nisi ipsis probantibus, docere non audeat; art. 45: omnes clerici qui ad operandum ualidi sunt, et artificiola et litteras discant. 
The content of Church legislation on education has been deeply influenced by local conditions, and thus an increased participation of synodal legislation, especially in Gaul and Spain, can be observed in the general bulk of canon law in matters of education in the subsequent centuries. In the sixth century, synods often underlined the need and necessity of educating the clergy, and at the same time they wanted to introduce closer control by the Church over the process of educating clerics and lay people ${ }^{20}$. The Synod held in Gallic Reims in 511 issued provisions regarding education and formation of priests ${ }^{21}$. The need for the organization of education is evident in the legislation of the Spanish Synods, usually held in Toledo. The Synod of Toledo of 527 convoked by metropolitan Montanus, by will and with the permission of the King of the Visigoths Amalric (511-531), deliberated, among other things, on the canons concerning the education of seminary students, celibacy, and priests' loyalty to their bishops ${ }^{22}$. A great example of ad hoc legislative action is the decision taken in 524 at the synod of Arles. It was then noticed that due to the growing number of churches, more priests were needed to be ordained, and therefore educated ${ }^{23}$. Decisions on the education of prospective priests in took the synod of Toledo in $527^{24}$. In 529 , the synod of Vaison ordered to establish schools at churches. They were to be staffed by priests whose task was to teach children to spell the alphabet, write on tablets and write with ink on parchment, and memorize the psalms ${ }^{25}$. Graduating from such a school was enough to be given priestly ordination or to take office in the secular or ecclesiastical administration ${ }^{26}$. We find similar provisions in canons of the Third Synod of Toledo of 589. 211.

${ }^{20}$ E.g. a synod held in 506; in art. 42, Concilium Agathense, [in:] Concilia Galliae A. 314-A. 506, pp. 210-

${ }^{21}$ Concilium Aurelianense, [in:] Concilia aevi Merovingici, recensuit F. MAASSEN, MGH, Legum sectio III: Concilia, vol. I, Hannoverae 1893. See: KUMOR, B., Historia Kościoła, vol. 2: Wczesne średniowiecze chrześcijańskie, sec. edition., Lublin 2005, p. 12.

${ }^{22}$ Stownik wczesnochrześcijańskiego piśmiennictwa, eds. J.M. SZYMUSIAK, M. STAROWIEJSKI SJ, Poznań 1971, p. 623; RICHÉ, P., Edukacja i kultura w Europie Zachodniej (VI-VIII w.), Warszawa 1995, p. 138; KUMOR, B., Historia Kościoła, vol. 2, p. 21.

${ }^{23}$ Tamen quia crescente ecclesiarum numero necesse est nobis plures clericos ordinare. As cited in: RICHÉ, P., Edukacja i kultura w Europie Zachodniej (VI-VIII w.), Warszawa 1995, p. 109.

${ }^{24}$ Canon 1: De his quos voluntas parentum a primis infantiae annis clericatus officio emancipavit statuimus observandum ut mox cum detonsi vel ministerio lectorum contraditi fuerint in domo ecclesiae sub episcopali praesentia a praepositio sibi debeant eruditi. At ubi octavum decimum aetatis suae compleverint annum coram totius cleri plebisque conspectus voluntas eorum de expetando conjugio ab episcopo perscrutetur. See: RICHÉ, P., Edukacja i kultura, p. 138; BANNIARD, M., Wczesne średniowiecze na Zachodzie, Warszawa 1998, p. 152; SZYMUSIAK, J.M., STAROWIEJSKI, M. SJ, Słownik wczesnochrześcijańskiego piśmiennictwa, Poznań 1971, p. 623.

${ }^{25}$ Hoc enim placuit ut omnes presbyteri qui sunt in parochiis constituti secundum consuetudinem quam per totam Italiam satis salubriter teneri cognovimus juniores lectores quantoscumque sine uxoribus habuerint secundum in domo ubi ipsi habitare videntur recipiant, et eos quomodo boni patres spiritaliter nutrientes psalmos povare divinis lectionibus insistere et in lege Domini erudiro contendant ut et sibi dignos successores provideant et a Domino praemia aeterna recipiant.

${ }^{26}$ MIŚKIEWICZ, M., Zarys kultury i archeologii Europy w okresie wczesnego średniowiecza, Warszawa 2002, p. 185; BANNIARD, M., Geneza kultury europejskiej, p. 87. 
The clerical education curriculum was also discussed at the Synod of Toledo in 633. Saint Isidore of Seville had already given, in canons 24-25, quite specific rules for the education and formation of would-be priests ${ }^{27}$. The specific rules for the formation and education of clerics are contained in Canons 24-25. The Bishop of Seville emphasized that clerics should be proficient in the Scriptures, psalms, hymns and songs in order to teach the believers more effectively ${ }^{28}$. These canons were also included in the collection of Anselm of Lucca. Clergymen were supposed to have proficient knowledge in the Scriptures to instruct the people and keep them in faith ${ }^{29}$. Generally speaking, the legislation of the sixcentury synods created the church education system consisting both of higher-level and cathedral-level schools as well as parish-level elementary schools. Let us note here that church schools were established beside, not instead of existing secular schools, and were considered rather as a supplement to the deficiencies in access to education than a new, independent school system. This first stage of the development of school church legislation was characterized by a certain local and provisional nature, and the content of the rules gives the impression of ad hoc activity.

The second period of development of the education related church legislation begins, in my opinion, with the reforms undertaken by the Carolingian rulers of the Frankish state in order to strengthen the statehood. The institutional church with its educated staff and library resources was treated as a tool in the reform process, and Charlemagne and his successors were consciously referring to the former prerogatives of Roman emperors. Various types of legal actions were undertaken by the hierarchs on the initiative of the ruler.

Bishop Theodulf of Orléans issued in 798 a capitulary on presbyteral schools. This paramount document is worth quoting in its entirety: Let priests have schools in villages and districts. If any fidelis wants to commend his young boys (parvulos) to them, they shall not refuse to teach them; but in accepting them let them teach them with greatest love (caritate) - - When, therefore, they teach them, they should demand no payment from them, nor receive anything from them save what the parents offer them in desire of charity of their own free will ${ }^{30}$. In 801, Teodulf also ordered that children be admitted to all

${ }^{27}$ Sentencia Isidori super Levitico, Collectio vetus Gallica, [in:] MORDEK, H., Kirchenrecht und reform, p. 378; BOBER, A. SJ, Antologia patrystyczna, Kraków 1965, p. 407.

${ }^{28}$ De libro Ysidori officiorum II, De regulis clericorum: - - perpetuo conservare student - - postremo in doctrina, in lectionibus, psalmis, hymnis, canticis exercitio rugi incumbent. Talis enim esse debent, qui divinis cultibus sese mancipandus student, scilicet, ut, dum scientiae operam dant, doctrine gratiam populis administrant, [in:] Die Collectio vetus Gallica, p. 513.

29 ANSELMI episcopi Luccensis, Collectio canonum, Ex Consilio Tolletano V: Ignorantia mater cunctorum errorum maxime in sacerdotibus Dei vitanda est quae docendi officium in populis susceperunt. Sacerdotes enim legere sanctas spirituas admonentur Paulo apostolo dicente ad Timotheu: Intende lectioni, exortationi dectrinae, semper permane in his. Sciant igitur sacerdotes scripturas sanctas et canones, ut omne opus eorum in predicatione et doctrina consistat, atque aedificent cunctos tam fidei scientia quam operum disciplina, p. 404. Omnis clerici, qui ad operandum validi sunt, et arteficiola et litteras discant, Canon Africanorum XLV, [in:] Die Collectio vetus Gallica, ps. 503.

${ }^{30}$ MGH, Capitularia, ed. BROMMER, P., s. 115-116; Polish translation: RICHÉ, P., Chrześcijaństwo na karolińskim Zachodzie, p. 596. 
schools regardless of whether they intend to devote themselves to clerical career or to live a secular life.

In the spirit of the Carolingian reforms, the school legislation also appeared in the statutes of the Synod of Mantua held in 827, during which the bishops were obliged to appoint, at all episcopal and municipal churches and where it would be needed, masters and doctors who would teach artes liberales and sancta dogmata ${ }^{31}$. It should be noted, however, that this ordinance failed to get a foothold on the Apennine Peninsula at that time. Moreover, the obligation to support schools by bishops appears very often in synodal decisions of this period ${ }^{32}$. The Paris Synod of 829 reminded parents that children had to be sent to school not only to learn reading, but to learn the basics of faith and, when back home, to teach the parents how to pray if they had forgotten the prayers ${ }^{33}$. The responsibility of supervising the work of schools was entrusted to Archdeacons. This obligation resulted from the recommendations of the Synod of Toulouse of 844 and the instructions of Bishop Hincmar of Reims ${ }^{34}$. All activities in the area of educational law undertaken during this period form part of the general recommendations contained in royal ordinances. The idea of the Carolingian reform of education, in practice aimed at restoring old forms and methods of education, was to open the access to education for lay people. For many reasons, the beneficiaries of the changes were few aristocrats. Nevertheless, the Charlemagne's will, owing to his collaborators, including Alcuin, Hildebrandt, the Archbishop of Cologne (791-819), Adalard, Abbot of Corbie, Richbod, Abbot of Lorch, Madoin, Bishop of Autun and others, influenced ecclesiastical legal norms. Theoretically, greater influence was exerted by the provisions regarding school curriculum included in Charlemagne's Admonitio Generalis dated 789. This document, although developed at the royal chancellery, was stemmed in the rules of canon law and Roman law, and was addressed, in the aspect of our interest, to the clergy. The King of Franks, in a document issued on 23 March at the general assembly of the Francs, stated that psalms, notes (and thus how to record music), computus (method of calculating the ecclesiastical calendar) and grammar should be taught in schools $^{35}$. A similar curriculum was provided by Charlemagne in a letter to the abbot of the Fulda monastery Baugulf, on the need to develop teaching and the development of monas-

${ }^{31}$ As cited in: KUMOR, B., Historia Kościoła, vol. 3: Złoty okres średniowiecza chrześcijańskiego, Lublin 2005, p. 113.

${ }^{32}$ E.g. cap. 5 of the synod of Bishop of Salzburg Arn held in Rispach in 798, MGH, Concilia I, no. 116, p. 234.

33 Concilium Parisense a. 829, Cap. XXX: Ut ab omnibus episcopis propter honorem et utilitalitem ecclesiasticam sollicitior circa habendas scolas cura habeatur, MGH, Concilia aevi Karolini, vol. II, p. 632; see RICHÉ, P., Chrześcijaństwo na karolińskim Zachodzie, p. 606.

${ }^{34}$ HINCMAR OF REIMS, Capitula quibus de rebus magistri et decani per singulias ecclesias inquirere, et episcopo renutinare debeant, $P L$, vol. 125, canon 11, col. 778.

${ }^{35}$ Admonitio generalis, [in:] MGH, Capitularia regum Francorum, vol. I, ed. G.H. PERTZ, Berlin 1835 (reprint 1991), no. 22, p. 59 et seq. See. FAŁKOWSKI, W., Admonitio generalis Karola Wielkiego-zapowiedź tworzenia państwa idealnego, [in:] Ludzie. Kościót. Wierzenia. Studia z dziejów kultury i społeczeństwa Europy Środkowej (średniowiecze - wczesna epoka nowożytna), eds. W. IWAŃCZAK, S.K. KUCZYŃSKI, Warszawa 2001, pp. 419-428. 
tery schools ${ }^{36}$. It should be emphasized that the King of the Franks addressed the issue of the school curriculum, ordering it to be implemented at every bishopric and every monastery. In addition, it was instructed that carefully revised books be collected in the places of study $^{37}$. It should not be ignored that one of reasons behind the Epistola de litteris colendis was the training of missionaries for the needs of the expanding empire, so the development of education was to serve the interests of the state ${ }^{38}$. Both acts were aimed at establishing a canon of minimum requirements for diocesan and monastic clergy within the empire ${ }^{39}$.

The above-discussed legal acts issued by secular authorities perfectly reflect the tendency for overlapping activities of the rulers and the Church. Under the influence of the role model of a ruler, developed in the Carolingian period and clearly referring to the ancient ideals, individual kings, identifying themselves as patrons of the Church in their respective realms entrusted to them by God in the act of anointing before the coronation, participated in lawmaking activities. Such actions were taken by Alfred the Great (871899), seeking to improve literacy in their own language among the laity, which, after all, required the consent of church authorities. The king wanted also the most talented young people to learn Latin in order to join the ranks of the clergy ${ }^{40}$.

In the ninth century, the Church's interest in the development of cathedral education was also noticeable. From the times of Eugene II (824-827), successive popes renewed decrees urging the bishops to run cathedral schools. To organise a school was not a simple thing during this period of political turmoil, since it required material resources, appropriate personnel and a library.

The next stage in the development of the church legislation in school matters was connected with the Gregorian reform and the so-called renaissance of the twelfth century, and it was also a response to the development of cities and the emergence of universities. The basic concepts of the Gregorian reform were related to the idea of return to the Church of the apostolic times, free from the influence of the state, or, more broadly, lay people. The reform can be treated as a response of the Church to the feudal transformation, urban and economic changes initiated in the 11th century, and its essence consisted in enforcing statutes and norms that had existed in the Church, often for centuries. However, these norms were dispersed and often mutually contradictory. The necessity of their arrangement formed the reason of the development of the canon law. The 12th century also

${ }^{36}$ KAROLI, Epistola de litteris colendis, [in:] MGH, Capitularia, vol. I, ed. A. BORETIUS, Hannover 1883; see also: WALLACH, L., "Charlemagne's De litteris colendis and Alcuin”, Speculum 26 (1951), no. 2 , pp. 288-305; FAŁKOWSKI ,W., Admonitio generalis Karola Wielkiego, p. 420.

${ }^{37}$ MGH, Capitularia regnum Francorum, I, p. 60.

38 EWIG, E. Das Zeitalter Karls des Großen, p. 100.

39 KIJEWSKA, A., Edukacja karolińska, [in:] Czasy katedr-czasy uniwersytetów. Źródła jedności narodów Europy, ed. W. SAJDEK, Lublin 2005, p. 170.

40 See PIENIĄDZ-SKRZYPCZAK, A., Ad imitationem eius quaedam instituere providimus capitula ... Działalność prawodawcza a kształtowanie się wizerunku władcy w księstwie Benewentu $w$ VIII-IX wieku, [in:] Monarchia $w$ średniowieczu. Władza nad ludźmi, władza nad terytorium. Studia ofiarowane Profesorowi Henrykowi Samsonowiczowi, eds. J. PYSIAK, A. PIENIĄDZ-SKRZYPEK, M.R. PAUK, Warszawa-Kraków 2002, pp. 73-96. 
brought a qualitative change in pedagogy due to the "discovery" of the child and the needs of childhood: affection, tenderness and atmosphere of trust between adults and children in was recognized as equally important as discipline in the upbringing of children. Pragmatic literacy appeared in this period: the ability to write and read became an indispensable element of everyday life ${ }^{41}$. The increased educational needs of burghers were also the reason that municipalities were gradually taking over the rights of patronage over municipal parish churches with schools functioning at them. This situation became evident especially in the thirteenth century, however we could see its first symptoms already in the period discussed. This new situation for the spiritual authorities needed to be legally regulated. Collegiate schools that, competing with parish schools, in the twelfth and thirteenth centuries offered studies to all willing to learn, found themselves in a new situation.

The transformations of the way of seeing the world and the emergence of new forms of teaching, namely universities, aroused due interest from the Church authorities, which reflected in the subject of the deliberations of the great reformatory councils that took place in the Roman basilica of San Giovanni in Laterano.

The Second Council of the Lateran, held on 2-17 April 1139 with the participation of 500 hierarchs, took decisions that were crucial from the point of view of the subject discussed by us, limiting the field of scientific interests of monks and regular canons. What may seem strange, the clergy were then forbidden the study of secular subjects ${ }^{42}$. The conclusion is that such secular subjects as Roman law and medicine were recognized as the domain of the world of profanum, and that lay people were acquiring knowledge in this field, though under the control of the Church. This was an important sign that the Church detached from secular affairs, although the bans on taking up legal studies by members of the clergy would be repeated many times.

The Third Council of the Lateran (1179) spoke on the issue of granting a licence to teach (licentia docendi), which was the beginning of activities aimed at regulating the rules of awarding academic degrees at universities ${ }^{43}$. Our attention can be drawn to Canon III (Quales debeant esse qui eligendi sunt ad regimen ecclesiae) and especially Canon XVIII - Ut prelati provideant magistris scholarum necessaria $)^{44}$. The former postulates that candidates for clergy are expected to get appropriate education, an this applies especially to bishops ${ }^{45}$. Canon XVIII obliged bishops to appoint a master at each cathedral

${ }^{41}$ POTKOWSKI, E., Moc księgi-przykład św. Bonifacego, [in:] Scriptura, custos, memoriae. Prace historyczne, ed. D. ZYDOREK, Poznań 2001, pp. 203-204.

42 Dokumenty soborów powszechnych, vol. II, p. 147, Canon IX: Ut monachi et regulares canonici leges temporales et medicinam non discant.

${ }^{43}$ See more in: COBBAN, A.B., The Medieval Universities. Their Development and Organization, Oxford 1975.

44 Dokumenty Soborów Powszechnych, vol. II, p. 171 et seq.

${ }^{45}$ Dokumenty soborów powszechnych, vol. II, p. 170: Cum in sacris ordinibus et ministeriis ecclesiasticis, et aetatis maturitas et morum gravitas et scientia litterarum sit inquirenda, multo forties haec in episcopo oporet inquiri, qui ad curam positus aliorum, in se ipso debet ostendere qualiter alios in domo Domini oporteat conversari. 
church, whose task was to teach, free of charge, both candidates for priesthood and secular students. This decision guaranteed, at least de iure, funds for the subsistence of teachers, and ensured the stable maintenance of all cathedral schools in the future. However, it should be noted that in practice it was not until the early 13th century that cathedral schools began their activity in the entire Christian Europe.

The Fourth Council of the Lateran (1215) raised a number of important issues in the matters of education in a wide sense ${ }^{46}$. The Council Fathers ordered in Canon XI De magistris scholasticis that in the cathedral or collegiate chapters a benefice should be granted for a theologian who, as a theology teacher, should teach the clergy pastoral ministries and teach them sacra pagina and preach. The pedagogical role of these theologians is of utmost importance due to the fact that they were to prepare collections of sermons to be preached to a wide circle of the faithful ${ }^{47}$. The canon cited here pointed out that many who wish to learn could not do it because of the lack of material resources and people who could teach $^{48}$. In this situation, it was decided that schools should be created not only in every cathedral church but also in other churches with sufficient resources. Teachers employed therein were to teach grammar and other branches of study, as far as is possible, to the clerics of those and other churches, free of charge $e^{49}$.

In the fourteenth century, there was an increase in the number of people immersed in literary culture, new libraries were established, also private ones, and literary creativity flourished. Such an atmosphere fostered the process of literacy, growth in the number of pupils at schools and students at universities. Church authorities had to find their way in a new situation which posed a threat of losing the monopoly in teaching. The situation of parish schools in cities was particularly complicated. As noted above, as early as in the twelfth century, first in Italy and Germany, schools widely opened their doors to burghers, merchants and officials who learned reading, writing, accounting etc. With time, there was a rapid development of municipal education, which, as noted in the literature of reference, was relatively loosely connected with the Church organisation. This was due to different cultural and educational needs of the burghers, which were only partially met by the existing school curriculum. It was also important that many issues concerning, for example, the meaning of life, bourgeois mentality manifesting in bourgeois culture affirming life through play, humanistic attitude, were understood differently, which the Church received without special enthusiasm, and which caused frequent conflicts between municipalities

${ }^{46}$ I discussed these issues earlier in: "Ustawodawstwo szkolne soborów od XII do pierwszej połowy XIV w. i początki jego recepcji w średniowiecznej Polsce - zarys problemu”, Biuletyn Historii Wychowania 23 (2007), p. 7-19.

${ }^{47}$ Zob. BRACHA, K., Teolog - intelektualista i duszpasterz w spoleczeństwie średniowiecznym, [in:] Kolory i struktury średniowiecza, ed. W. FAŁKOWSKI, Warszawa 2004, pp. 136-154; idem, Wokót tysogórskich kolekcji kazań z XV w. przypisywanych Piotrowi z Miłosławia. W kręgu malżeństwa i rodziny, [in:] Klasztor na Świętym Krzyżu w polskiej kulturze narodowej, eds. D. OLSZEWSKI and R. GRYZ, Kielce 2000.

${ }^{48}$ Quia nonnulis propter inopiam et legendi studium et opportunitas proficiendi subtrahitur. Dokumenty Soborów Powszechnych, vol. II, p. 246.

49 Ibidem, p. 247. 
and the Church authorities. Some aspects of lawmaking taken in individual metropolises will be discussed in the final part of the paper. Still, the key issues in ecclesiastical education were the concern of the hierarchs participating in ecumenical councils.

The Council of Vienne (1312), in Canon XXIV, ordered that language classes in Hebrew, Arabic and Chaldean be provided at the Paris, Oxford, Bologna and Salamanca Universities. For the Paris University, the sufficient remuneration for the lecturers was to be provided by the king of France, while for the Oxford University this was a responsibility of the university authorities, monasteries, chapters, conventions, clergy's colleges, in other words, institutions delegating students to learn these languages ${ }^{50}$. Similar courses were also to be organised at the Roman Curia. In addition, the Council's documents edited by Pope John XXII include provisions regarding the teaching of the faithful by preachers from Dominican and Franciscan orders, competing in this respect with parish clergymen $^{51}$.

In the legislation of the Basel Council (1431-1445), it is worth noting that it emphasized the importance of convening annual diocesan synods, as well as holding regular provincial synods, during which priests were to be instructed on important matters, probably concerning education as well ${ }^{52}$. The Council also decided on founding schools to educate missionaries and on establishing appropriate scholarships for students ${ }^{53}$. The further part of the decree was about the preventing Jews from taking teacher positions in schools ${ }^{54}$.

A kind of summary of the late medieval legislation of ecumenical councils on the matters of education were the canons of the Fifth Council of the Lateran (1512-1517), held in the atmosphere of dominance of new intellectual trends, and at the same time on the eve of the Reformation. The Council ordered that elementary (parish) schools be established to teach grammar, rhetoric, truths of faith, ecclesiastical singing, liturgy and prayers free of charge.

${ }^{50}$ Ut igitur peritia linguarum - - per instructionis efficaciam obtineri, hoc sacro approbante concilio scholas in subscriptarum linguarum generibus, ubicunque Romanam curiam residere contigerit, nec hoc in Parisiensi et Oxoniensi, Bononiensi, et Salamantino studiis providimus erigendas, statuentes ut in quolibet locorum ipsorum teneantur viri catholici, sufficientem habentes Hebraicae, Arabicae et Chaldaeae linguarum notitiam, duo videlicet uniuscuiusque linguae periti, qui scholas regant inibi, et libros de linguis ipsis in Latinum fideliter transferantes, alios linguas ipsas solicite deceant earumque peritiam studiosa" etc., Dokumenty soborów powszechnych, vol. II, p. 582.

${ }^{51}$ Council of Vienne, Decree 10. 5, [in:] Dokumenty soborów powszechnych, vol. II, p. 551 The matter of monastic legislation goes beyond the assumed framework of this paper, and due to its vast scope requires a separate discussion.

${ }_{52}$ Postea legantur statuta provincialia et synodalia, et inter alia aliquis compendiosus tractatus, docens quomodo sacramenta ministrari debeant, et alia utila pro instructione sacerdotum, [in:] Dokumenty soborów powszechnych, vol. II, p. 320.

53 - - rectores ipsorum studiorum inter alia, quae in assumptione rectoratus iurent, hoc etiam addi volumus, operam se pro ipsius constitutionis observatione daturos - - in quibus provinciarum huiusmodi studia constituta sunt, omnio disponantur, ut hi, qui praedictas linguas doctui sunt, stypendia debita percipere voleant, [in:] Dokumenty soborów powszechnych, vol. II, p. 346.

54 Ibidem, p. 347. 
The interest in education was demonstrated by individual popes, and starting form Pope Gregory, they supported this issue with appropriate legal acts. Pope Gregory the Great (540-604) recommended in his ordinances that singing, reading and writing in Latin be taught in church schools. Before this, if the papacy spoke about secular education, this opinion concerned gentleness in bringing up children. In the 5th century, Pope Leo the Great reminded the people of Christ's fondness to children, treated by him as a model of innocence $^{55}$. It should be said that the Pope opposed a certain tradition of rigorous upbringing promoted by some Christian writers, e.g. Saint Ambrose ${ }^{56}$.

Pope Eugene II (824-827), under the clear influence of the Carolingian educational models, ordered in 826 to establish schools in every diocese. He also recommended that monastic schools admit also those boys who did not declare to become a monk ${ }^{57}$. The following citation is especially noteworthy: we order that in every episcopal seat and elsewhere, masters and doctors shall be appointed, if necessary, for teaching young boys grammar and liberal arts, because they make it easier to understand the divine commandments and explain them to others ${ }^{58}$. Pope Leo IV also issued an ordinance of similar wording. Namely, he ordered in the year 853 to establish elementary schools also in parishes. This law made a real contribution to the increase in the number of schools in Italy, but it only was of local significance, not becoming the norm of universally applicable law.

As a result of the Gregorian reform, papal decrees were of the same legal effect as Council statutes. They formed an important source of ecclesiastical law. Individual popes issued decrees with varying frequency. Worth distinguishing was undoubtedly Alexander III, who during his pontificate (1159-1181) issued about 700 decrees $^{59}$. The

55 Amat Christus infantiam, quam primum et animo suscepit et corpore. Amat Christus infantiam humilitatis magistram, innocentiae regulam, mansuetudinis formam. Amat Christus infantiam, ad quam majorum dirigit mores, ad quam senum reducit aetates et eos ad suum inclinat exemplum, quos ad regnum sublimat aeternum, Leo the Great, Sermones, XXXVII, cap. 3, [in:] SANCTI LEONIS Magni, Opera Omnia, vol. 1, Patrologia Latina, vol. LIV, Paris 1881, p. 258-259.

${ }^{56}$ Ambrose used to say: The pedagogues are considered to be unpleasant, severe and annoying, because they cause fear with beating, because they do not allow for coltish behaviour, because they demand discipline, because they keep children's minds in check in order not to let them be too rampant, tying them with horror. It is this severity that improves children so that they become honest, sober, self-restrained, they rather seek a praise than fun, SAINT AMBROSE, Hexameron, [in:] Pisma starochrześcijańskich pisarzy, vol. IV, Warszawa 1969, p. 204. John Chrysostom (died 407) spoke also in a similar tone in the work Vainglory and children.

${ }^{57}$ Canon 34: De scolis reparandis pro studio litterarum, Synod of Rome of 826: De quibusdam locis ad nos refertur non magistros neque curam inveriri pro studio litterarum. Iderico in universis episcopiis subiectisque plebibus et aliis locis, in quibus necessitas occurrerit, omnio cura et diligentia habeatur, ut magistri et doctores constituantur, qui studia litterarum liberaliumque atrium ac sancta habentes dogmata, assiduae doceant, quia in his maximae divina manifestantur atque declarantur mandata, [in:] MGH, Concilia, vol. II: Concilia aevi Karollini, ed. A. WERMINGHOFF, Hannoverae-Lipsiae 1916, p. 581. For the subject of educating both the clergy and lay people, see: Capitula admonitionis ab Eugenio II proposita (Synod of Rome), ibidem, p. 556-557.

${ }^{58}$ Polish translation: Historia wychowania, vol. 1, p. 188.

59 LANDAU, P., Kanonistische Ergänzungen zur Germania und Bohemia Pontificia. Päpstliche Dekretalen an Emfänger im Reich zwischen 1140 und 1198, [in:] Sacri canones servandi sunt. Ius canonicum et status ecclesiae saeculis XIII-XV, ed. P. KRAFL, Praha 2008, p. 242. 
Pope granted the Church the exclusive right to control teaching in all schools and to require from teachers a licence to practice their profession, issued by capitular scholastics. Alexander III pointed out that these licences were to be issued free of charge, but often there was abuse in this respect. The Pope announced twice, in 1160 and 1170, about severe penalties for charging fees when issuing the licentia docendi ${ }^{60}$.

Particular attention must be paid to the letter of Pope Alexander III of October 20, 1170-1172, that introduced the term licentia docend $i^{61}$. The privilege to issue this licence was clearly defined in this document and had a significant impact on the development of universities. In practice, the Pope granted the Church the right to control teaching in all schools and to require teachers to be licensed by chapter scholastics in order to conduct their teaching activities. Alexander III, in the orders of 1160 and 1170, pointed out that teaching licences should be issued free of charge, and threatened with severe penalties for violating this obligation, which suggests that numerous abuses were occurring in this re$\operatorname{gard}^{62}$.

The decrees of Pope Gregory IX (1227-1241) of 1234 pertained to parish churches and imposed on their administrators the obligation to run schools and teach the faithful: presbyter habens populum debet habere clericum, qui secum cantet et aliis hic expressis eum iuvet, ut quisque presbyter, qui plebem regit, clericum habeat, qui secum cantet, et epistolam et lectionem legat, et qui possit scholas tenere, et monere suos parochianos, ut filios ad fidem discendam mittant ad ecclesiam, quos ipse cum omni castitate erudiat ${ }^{63}$. This decree repeats previous legal acts, demonstrating the will of the papacy to support the mass education at parishes. On the other hand, this also indicates the difficulties in implementing the principles of the Fourth Council of the Lateran. It is worth noting once again the significance of this canonical collection, consisting of about 2000 paragraphs, constituting the basic body of canon law before $1918^{64}$.

Around 1300, Guillaume Durrand the Younger summed up relevant activities of the popes in the following way: Bishops ought to appoint masters in cathedral churches and main parish churches to teach poor students for free - - and a tenth of all ecclesiastical benefices - - should be given to poor masters at university faculties, because the Church of God will achieve enlightenment thanks to them ${ }^{65}$.

In 1339, Pope Benedict XII issued the bull Ad decorem ecclesiae, by which he obliged the superiors of monasteries throughout Christian Europe to send at least two monks from each monastery to study. This Pope also issued a number of documents governing the mat-

${ }^{60}$ Historia wychowania, vol. I, ed. Ł. KURDYBACHA, Warszawa 1967, p. 192.

${ }^{61}$ ALEKSANDER III, Epistola et privilegia 87, [in:] PL, vol. 200, p. 741.

${ }^{62}$ Historia wychowania, vol., 1, pp. 191-192.

${ }^{63}$ Corpus Juris Canonici, ed. E. FRIEDBERG, vol. 2, Leiden 1881, szp. 449, Decree III, tit. 1, Cap. III.

${ }^{64}$ In 1918, the Code of Canon Law was developed.

${ }^{65}$ GUILlaUME DURRAND THE YOUNGER, De modo generali concilii celebrandi, 2, 4, 16, [in:] Tractatus universi juris, duce et auspicje Gregorio XIIII, vol. XIII, Venetiis 1585, p. 156; Polish citation from: MUNDY, J.H., Europa średniowieczna 1150-1309, Warszawa 2001, p. 309. 
ters of education in individual convents, which, however, goes beyond the scope of this paper. In the later period, in the face of weakened position of popes, especially during the so-called Avignon Captivity, their legislative activities diminished and concerned mainly the university affairs.

In subsequent centuries, the episcopates of particular ecclesiastical provinces made legislative changes in response to emerging problems. It is impossible to discuss here all these provisions, so we will present selected historical documents of education-related legislation of the metropolis of Gniezno and selected neighbouring archbishops ${ }^{66}$. Local churches were supported and stimulated in the field of legislative action by papal legates, and in the later period, permanent apostolic nuncios, who took care of proper reception of universal law provisions in individual dioceses ${ }^{67}$. Law has greatly influenced the formation of the school network ${ }^{68}$. Interestingly, the inquiry about legislation of the dioceses adjacent to the Polish ecclesiastical province showed that there was very little interest in education matters. In German dioceses, the question of parish education appeared in the synodal legislation of the Archbishop of Cologne Engelbert II, who sought intensively in 1270 for the dynamic development of schools in his diocese, ${ }^{69}$ and of bishop Reinbotos (1279-1297) of $1283 .^{70}$ The first provision in the legislation of the diocese of Prague strictly on education was the ninth statute of the synod held on 18 October 1390 regarding staff shortages among auxiliary staff in schools of the Diocese of Prague ${ }^{71}$. The second sign evidencing the response of the Czech episcopate to problems in schools comes from 1404, and concerns the phenomenon of travelling bachelors and scholars ${ }^{72}$. A few years later, a statute appeared to counter the teachings of John Wycliffe spreading among Czech students and

${ }^{66}$ See more in: RATAJCZAK, K., Edukacyjne aspekty ustawodawstwa Kościoła w Polsce średniowiecznej, [in:] Szkoła polska od średniowiecza do XX wieku między tradycja a innowacja, eds. I. SZYBIAK, A. FIJAŁKOWSKI, J. KAMIŃSKA, with collaboration of K. BUCZEK, Warszawa 2010, pp. 19-32.

${ }^{67}$ I specify the literature of reference for this problem in: RATAJCZAK, K., "Legaci apostolscy w wiekach średnich i ich rola w przyjmowaniu partykularnego ustawodawstwa kościelnego przez Kościół polski aspekty edukacyjne", Biuletyn Historii Wychowania 26 (2010) [edition of 2011], pp. 7-17.

${ }^{68}$ See for example: RATAJCZAK, K., "XIII wiek - stulecie przełomu w dziejach średniowiecznego szkolnictwa w Polsce", Biuletyn Historii Wychowania 25 (2009), Poznań 2010, pp. 7-20; idem, Przyczyny powstania i rozwój sieci szkót kościelnych w średniowiecznej Wielkopolsce, [in:] Z dziejów polskiej kultury i oświaty od średniowiecza do początków XX wieku, eds. K. JAKUBIAK, T. MALISZEWSKI, Kraków 2010, pp. 165-180. Refer here for further literature.

${ }^{69}$ HARTMANN, W., Kirche und Kirchenrecht um 900. Die Bedeutung der spätkarolingischen Zeit für Tradition und Innovation im kirchlichen Recht, Hannover 2008, p. 490.

70 FLACHENECKER, H., Das beständige Bemühen und Reform. Zu Synoden und Synodalstatuten in den fränkichen Bistümern des 14./15. Jahrhunderts, [in:] Partikularsynoden im späten Mittelalter, hrsg. N. KRUPPA, L. ZYGNER, Göttingen 2006 [Veröffentlichungen des Max-Planck-Instituts für Geschichte, Band 219, Studien zur Germania Sacra Band 29], pp. 62-63.

${ }^{71}$ Item in scolis non teneant nisi honestos socios, [in:] Pražské synody a koncily přdhusitské doby, eds. J.V. POLC, Z. HLEDÍKOVÁ, Praha 2002, p. 254.

72 Ibidem, p. 270: Item mandat omnibus clericis vagabundis et discolis sub pena excommunicationis eterne et carcerali, ut infra mensem exeant de dyocesi et civitate et de sede etc. 
teachers as well as professors and students of the University of Prague. His books were to be withdrawn from circulation and deposited in the cathedral vault ${ }^{73}$.

In Polish dioceses, the increase in interest in education affairs can be clearly seen in the second half of the thirteenth century, which was a response to cultural changes related to colonization under German law, and in the fifteenth century due to problems resulting from a significant increase in the number of schools, decrease in the quality of teaching staff and the level of teaching itself ${ }^{74}$. The fact that intensity of student migration also increased, partly related to the Hussite movement in Bohemia, was also significant ${ }^{75}$. The period of turmoil led some people to unlawfully obtain academic titles, by which the candidates for teachers concealed their ignorance and ineptitude. The diocese of Wrocław fought against such candidates with relevant legal provisions (of 1476) ${ }^{76}$. The bishop and the chapter also attached great importance to the proper education of canons, obliging student canons to notify the bishop and the chapter about each resumption or interruption of studies at given universities ${ }^{77}$. Also, provisions regarding the conditions for obtaining a scholarship were issued ${ }^{78}$.

In 1285, Archbishop Jakub Świnka (1283-1314) strongly defended the Polish language at the synod of Łęczyca ${ }^{79}$. According to a statute issued by the archbishop, the good command of Polish was an important criterion when appointing for teacher positions ${ }^{80}$. Only priests and school principals having a good command of Polish, capable to explain Latin authors in Polish, were appointed for a given position ${ }^{81}$. The archbishop's reaction was a response to the rapid increase in the number of German clergy, especially in Silesian

${ }^{73}$ Statute 2 of teh Synod of Prague of 16 June 1410, [in:] Pražské synody a koncily přdhusitské doby, p. 291. Statute 6 (p. 294) contains a list of Wycliffe's texts that were forbidden, as heretic literature, to be read by the students.

${ }^{74}$ For a general outline of the subject, see: KAŁWA, P., Rys historyczny prowincjonalnego ustawodawstwa synodalnego w Polsce przedrozbiorowej, [in:] Księga pamiattkowa ku czci J.E.X. biskupa Mariana Leona Fulmana, part 1: Wydziały kościelne, Lublin 1939, s. 126-155; SAWICKI, J. "Ze studiów nad synodami diecezji wrocławskiej w XIII wieku”, Prawo Kanoniczne 4 (1961), vol. 1, pp. 173-209; FĄKA, M., "Synody arcybiskupa Henryka Kietlicza (1199-1219)”, Prawo Kanoniczne 12 (1969), vol. 3-4, pp. 95-127.

75 This fact is somehow related with Statute LVI De oratione scolarium of the codification of Mikołaj Trąba.

${ }^{76}$ Synody diecezji wroctawskiej $i$ ich statuty. Based on material colleted with the collaboration of A. SABISCH, compiled by J. SAWICKI, Concilia Poloniae. Źródła i studia krytyczne, vol. X, Wrocław 1963, p. 117.

77 Ibidem, p. 120.

78 Ibidem, p. 125.

79 For the activity of the Archbishop, see: SILNICKI, T., GOŁĄB, K., Arcybiskup Jakub Świnka i jego epoka, Warszawa 1956; KARASIEWICZ, W., Jakub Świnka, arcybiskup gnieźnieński (1283-1314), Poznań 1948; NOWACKI, B., Arcybiskup Jakub Świnka - budziciel i propagator polskiej świadomości narodowej, [in:] 1000 lat archidiecezji gnieźnieńskiej, pp. 107-120.

${ }^{80} \mathrm{KDW}$, vol. I, no. 551, p. 511.

${ }^{81}$ Ibidem: - - ponatur rectores scolarium, nisi linguam Polonicam proprie sciant, et possint pueris auctores exponere in Polonica lingua. 
cities rearranged under German law, where German-language schools were organized. A certain follow-up of the struggle that took place in the last decades of the 13th century with the influx of German-speaking teachers to schools was the statute XVIII of Synod of Uniejów of 19 February $1326^{82}$.

During the 15th century, individual dioceses forming part of the Metropolis of Gniezno tried to solve local problems at their synods. The synod of the diocese of Wrocław of 1406 focused, among other things, on the selection of the appropriate teaching staff, limiting the participation of monks in the teaching of secular sciences ${ }^{83}$. The Bishop Jan Szafraniec's Statutes of Krakow dated 1408 contained Canon 17 De magistris scholas regentiganico hucusque seruato per christianos ${ }^{84}$. It stated that one of the reasons for the clergy's moral decline in the diocese of Krakow was the large number of schools in towns and villages, which resulted in a situation in which "unruly and ignorant bachelors" taught in them ${ }^{85}$. As Stanisław Bylina notes, at almost the same time, in 1413, the diocese of Olomouc categorically forbidden to establish new schools in rural parishes, due to tha fact that the schools were poor and their teachers were poorly paid. The Bishop of Olomouc explained his decision by the fact that due to low remuneration for teachers, such jobs were taken by people lacking proper skills for this occupation. He also presented the deplorable ethical condition of students and their educators ${ }^{86}$. The local specificity was also reflected in Statute 59 of the diocese of Poznań from the synod convoked by Bishop Andrzej Bniński (1439-1479), De ovacione scholarium, prohibiting school rectors to celebrate boisterous-

82 Synody diecezji wrocławskiej $i$ ich statuty, p. 349: Precipimus, quod statum felicis recordacionis domini Iacobi quondam Gniznensis archiepiscopi nostri predecessoris de non recipiendis personis alienis in terra Polonie ad beneficia ecclesiarum curam habencia et magistros ad regimen scolarum non assumendis, nisi Polonicam linguam sciant, cum inibi se utiliter exercere, ab omnibus inviolalibiliter observetur, alioquin ad quos institucis seu discosicio pertinet eorundem, si contravenerint, ingressum ecclesie fore sibi noverint interdictum.

${ }^{83}$ Synody diecezji wrocławskiej i ich statuty, statut XIX, p. 373: Doctores quoque sive magistri, qui religiosos, habitu suo dimisso, leges vel physicam audientes, vel scienter docere in scholis suis presumpserint vel retinere, sunt excommunicati ipso facto, ut in fine dicti. Ne clerici vel monachi.

${ }^{84}$ ULANOWSKI, B., "Statuty diecezjalne krakowskie z roku 1408", Archiwum Komisji Historycznej AU'5 (1889); see also: ZYGNER, L., Drei polnische Bischöfe und Juristen Peter Wysz, Jakob aus Kurdwanów, Andreas Laskarii und ihre Synodaltätigkeit in den Diözesen Krakau, Płock und Posen, [in:] Partikularsynoden im späten Mittelalter, pp. 239-273.

${ }^{85}$ Statuty diecezjalne krakowskie z roku 1408, ed. B. ULANOWSKI, [in:] „Archiwum Komisji Historycznej PAU”, vol. V, Kraków 1889, p. 26: Item cum defectus morum et scienciarum plurium in dioecesi Cracoviensi provenit ex multiplicatione scolarum in oppidis parvis et villis, ubi nec moribus, nec in disciplinis sunt directores et sic nec in scientiis, nec in moribus, ut expedit in dictis scolis scolares instruuntur, immo pocius negliguntur et ita postea ad sacros ordines promoverunt, quare mandamus, quatinus nulli adolescentes scolares in predictis scolis, ubi nec in disciplinis, nec in moribus instruuntur, forveantur, sed pueruli, quibus ibi suppetit facultas dicendi foveantur, nisi esset magister vel baccalarius, qui salubriter eos in doctrina et in moribus dirigeret et in disciplinis confoveret. Polish translation as published in: FIJAŁEK, J., Życie i obyczaje kleru w Polsce średniowiecznej na tle ustawodawstwa synodalnego, edition II, Kraków 2002, p. 32 [first printed as Średniowieczne ustawodawstwo synodalne biskupów polskich, part 1: Życie i obyczaje kleru w Polsce średniowiecznej na tle ustawodawstwa synodalnego, „Rozprawy Akademii Umiejętności, Wydział Historyczno-Filozoficzny”, series II, vol. V, Kraków 1894, pp. 181-239]. See: ULANOWSKI, B., Kilka uwag o statutach synodów diecezjalnych krakowskich z XIV i XV wieku, Kraków 1888, p. 26.

${ }^{86}$ BYLINA, S., Statuty synodalne jako instrument chrystianizacji wsi, p. 276. 
ly together with the students ${ }^{87}$. In 1456, a diocesan synod was held in Gniezno, which instructed all senior students of parish schools in the diocese to move to a university, cathedral school or to collegiate schools, in which bachelors and atrium masters taught ${ }^{88}$. In 1477, the ordinances of Bishop of Wrocław Zbigniew Oleśnicki (1473-1480) were issued, in which he ordered school rectors to carefully investigate among their students and inform about the cases of the appearance of the Czechs, contaminated with the sin of Hussitism $^{89}$. The Bishop stressed that at every parish church a school should be located, in which would-be priests must be taught good manners, virtues and certain knowledge. The schools were not allowed to admit students of Czech nationality ${ }^{90}$.

In 1510, the provincial synod of Piotrków tried to counter uncontrolled student migrations. School principals were required to screen out young people and leave only students who really wanted to study at school ${ }^{91}$. This question was also discussed again in $1512^{92}$. The canon of the synod celebrated by Archbishop Jan Laski was that wandering school students who would not return to school within three days shall be reported by the parish priests to the district official for the purpose of punishing, including even corporal pun$i_{\text {shment }}{ }^{3}$. Another issue of our interest was restricting the requirements for candidates for teachers. Well-educated people keeping good ethical standards were to be chosen for principals of cathedral, collegiate and parish schools ${ }^{94}$.

The remarks made above do not fully describe the subject, for example we left out the issue the education-related legislation of religious orders. We discussed this topic elsewhere. However, the presented material presented turning points in the history of school legislation of the Church: from its origins related with civilisational changes in the Roman Empire, or more specifically in its western part, which gradually degenerated. In the first

${ }^{87}$ Statuta diocesana ecclesie Poznaniensis, [in:] Synody diecezji poznańskiej i ich stauty, SAWICKI, J., Concilia Poloniae. Źródta i studia krytyczne, vol. VII, Poznań 1952, p. 160.

${ }^{8}$ SAWICKI, J. Synody archidiecezji gnieźnieńskiej i ich statuty, Warszawa 1950 [Concilia Poloniae. Źródła i studia krytyczne, vol. V], p. 62; Statuta a sinodo diocesiani Gneznensi promulgata, ed. B. ULANOWSKI, [in:] Acta capitulorum nec non iudiciorum ecclesiasticorum selecta, ed. B. ULANOWSKI, vol. 1: Acta capitulorum gneznensis, poznaniensis et vladislaviensis (1408-1530), Kraków 1894, no. 1860, p. 422.

89 Statuta diocesana Sbignei episcopi anno 1477, [in:] Statuta synodalia dioecesis Wladislaviensis et Pomeraniensis, ed. M. CHODYŃSKI, Warszawa 1890, pp. 20-23.

${ }^{90}$ Ibidem, p. 23; see also: KARBOWIAK, A., "Szkoła katedralna kujawska w wiekach średnich", Kwartalnik Historyczny 12 (1898), pp. 763-777.

91 SUBERA, I., Synody prowincjonalne arcybiskupów gnieźnieńskich, Warszawa 1971, p. 98. Recently scholars have moved the date of this synod to 1511: cf. TYMOSZ, S., Szkic historyczno-biograficzny prymasa Jana Laskiego (1456-1531), [in:] Arcybiskup Jan Laski reformator prawa, ed. S. TYMOSZ, Lublin 2007, p. 35 .

92 SUBERA, I., Synody prowincjonalne arcybiskupów gnieźnieńskich, p. 101; PELCZAR, R., "Ustawodawstwo synodów diecezjalnych i listy pasterskie biskupów wobec szkolnictwa kościelnego dla świeckich w Polsce od XIII do XVIII wieku", Archiwa, Biblioteki i Muzea Kościelne 67 (1997), p. 325 et seq.

93 The text, according to manuscript no. 2834 of the Library of the Jagiellonian University, is presented by I. Subera, Synody prowincjonalne, p. 80.

94 SUBERA, I., Synody prowincjonalne, p. 79. 
period, the Church authorities at the level of diocese or archdiocese made decisions to prevent on-going threats to the process of personnel reproduction. The second stage, in the Carolingian period, involves attempts of the Church authorities to implement the recommendations of secular authorities. Due to common goals, a peculiar symbiosis was also visible in the Ottonian Church or in the newly Christianized countries of Central and Eastern Europe. With time, however, under the influence of the Gregorian reform, there was a growing tendency to arrange corporate church education for future clergy and monks, and with the concern for the spiritual formation of lay people seen in the legislation. The fourth stage of the development of school church legislation identified by us was related to the realities of enormous social and economic changes that took place in Europe in the 12th and 13th centuries, and led to a new situation in the field of education, increasingly controlled by secular people. Finally, in the late Middle Ages, the Church focused primarily on attempts to maintain control over universities and activities aimed at maintaining the highest possible intellectual level of the clergy. It was also forced to respond, on an ongoing basis, to numerous problems of schools functioning in particular metropolises, which resulted from the specificity of cultural, economic and social development in Europe of the late Middle Ages. The remarks made here should be treated as an outline to encourage further scientific discussion on this important subject that needs in-depth studies.

\title{
Literature of Reference
}

\author{
I. Sources
}

Admonitio generalis, [in:] MGH, Capitularia regum Francorum, vol. I, ed. G.H. PERTZ, Berlin 1835 (reprint 1991), no. 22.

ALEKSANDER III, Epistola et privilegia 87, [in:] PL, vol. 200.

AMBROSE, Hexameron, [in:] Pisma starochrześcijańskich pisarzy, vol. 2, Warszawa 1969.

ANSELMI EPISCOPI LUCCENSIS, Collectio canonum, una cum collectione minore iussu institute savigniani, ed. F. THANER, Insbruck 1906.

Concilia aevi Karolini, vol. II, ed. A. WERMINGHOFF, [in:] MGH, Legum sectio IV: Concilia, vol. 2, Hannoverae-Lipsiae 1906.

Concilia aevi Merovingici 511-695, recensuit F. MAASSEN, MGH, Legum sectio III: Concilia, vol. I, Hannoverae 1893.

Concilia aevi Merovingici, recensuit F. MAASSEN, MGH, Legum sectio III: Concilia, vol. I, Hannoverae 1893.

Corpus Juris Canonici, ed. E. FRIEDBERG, vol. 2, Leiden 1881.

Die Collectio vetus Gallica. Text mit kritischen Apparat und Quellenkommentar, [in:] MORDEK, H., Kirchenrecht und reform im Frankenreich. Die Collectio vetus Gallica. Die Älteste systematische kanonessammlung des Fränkischen Gallien. Studien und edition, Berlin-New York 1975 [Beiträge zur Geschichte und Quellenkunde des Mittelater, hrsg. v. H. FUHRMANN, Bd. 1].

Dokumenty soborów powszechnych, vol. III: 1415-1445, compiled by: A. BARON, H. PIETRAS SJ, Kraków 2007.

Dokumenty Soborów Powszechnych. Tekst grecki, łaciński, polski, vol. II: (869-1312), compiled by: A. BARON, H. PIETRAS, Kraków 2002. 
Dokumenty soborów powszechnych. Tekst łaciński, grecki i polski, vol. 1, compiled by: A. BARON, H. PIETRAS SJ, Kraków 2001.

HINCMAR OF REIMS, Capitula quibus de rebus magistri et decani per singulias ecclesias inquirere, et episcopo renutinare debeant, PL, vol. 125.

KAROLI, Epistola de litteris colendis, [in:] MGH, Capitularia, vol. I, ed. A. BORETIUS, Hannover 1883.

Kodeks Dyplomatyczny Wielkopolski, vol. I, Poznań 1877.

LEO THE GREAT, Sermones, XXXVII, cap. 3 [in:] Sancti Leonis Magni, Opera Omnia, vol. 1, Patrologia Latina, vol. LIV, Paris 1881, pp. 258-259.

Pražské synody a koncily přdhusitské doby, eds. J.V. POLC, Z. HLEDÍKOVÁ, Praha 2002.

SAWICKI J., Synody archidiecezji gnieźnieńskiej i ich statuty, Warszawa 1950 [Concilia Poloniae. Źródła i studia krytyczne, vol. V].

Statuta a sinodo diocesiani Gneznensi promulgata, ed. B. ULANOWSKI, [in:] Acta capitulorum nec non iudiciorum ecclesiasticorum selecta, ed. B. ULANOWSKI, vol. 1: Acta capitulorum gneznensis, poznaniensis et vladislaviensis (1408-1530), Kraków 1894.

Statuta diocesana ecclesie Poznaniensis, [in:] Synody diecezji poznańskiej i ich stauty, J. SAWICKI, Concilia Poloniae. Źródła i studia krytyczne, vol. VII, Poznań 1952.

Statuta diocesana Sbignei episcopi anno 1477, [in:] Statuta synodalia dioecesis Wladislaviensis et Pomeraniensis, ed. M. CHODYŃSKI, Warszawa 1890, pp. 20-23.

Statuta ecclesiae antiqua, [in:] Concilia Galiae A. 314-A. 506, cura et studio C. MUNIER, Corpus Christianorum. Series Latina, vol. CXLVIII, Turnhout 1963.

Statuty diecezjalne krakowskie z roku 1408, ed. B. ULANOWSKI, [in:] „Archiwum Komisji Historycznej PAU”, vol. V, Kraków 1889.

Synody diecezji wroctawskiej $i$ ich statuty. Based on material colleted with the collaboration of A. SABISCH, compiled by J. SAWICKI, Concilia Poloniae. Źródła i studia krytyczne, vol. X, Wrocław 1963.

TERTULIAN, De idolalatria, t. 10, eds. J.H. WASZNIK, J.C.M. WINDEN, Leiden 1987.

GUILLAUME DURRAND THE YOUNGER, De modo generali concilii celebrandi, 2, 4, 16, [in:] Tractatus universi juris, duce et auspicje Gregorio XIIII, vol. XIII, Venetiis 1585.

\section{Studies}

ABT, S., Święty Augustyn jako pedagog, Kraków 1930.

BANNIARD, M., Wczesne średniowiecze na Zachodzie, Warszawa 1998.

BOBER, A. SJ, Antologia patrystyczna, Kraków 1965.

BRACHA, K., Teolog - intelektualista i duszpasterz w spoteczeństwie średniowiecznym, [in:] Kolory i struktury średniowiecza, ed. W. FAŁKOWSKI, Warszawa 2004, pp. 136-154.

BRACHA, K., Wokót tysogórskich kolekcji kazań z XV w. przypisywanych Piotrowi z Miłosławia. W kręgu matzeństwa i rodziny, [in:] Klasztor na Świętym Krzyżu w polskiej kulturze narodowej, eds. D. OLSZEWSKI and R. GRYZ, Kielce 2000.

BROWN, P., Augustyn z Hippony, Warszawa 1993.

BYLINA, S., Statuty synodalne jako instrument chrystianizacji wsi w późnym średniowieczu, [in:] Sacri synodes servandi sunt. Ius canonicum et status ecclesiae saeculis XIII-XV. Kolektivni monografie, ed. P. KRAFL, Praha 2008.

COBBAN, A.B., The Medieval Universities. Their Development and Organization, Oxford 1975.

DEVROEY, J.-P., Gospodarka, [in:] Zarys historii Europy. Wczesne średniowiecze od 400 do 1000 r., ed. R. MC KITTERICK, Warszawa 2003.

FAŁKOWSKI, W., Admonitio generalis Karola Wielkiego - zapowiedź tworzenia państwa idealnego, [in:] Ludzie. Kościół. Wierzenia. Studia z dziejów kultury i społeczeństwa Europy Środkowej 
(średniowiecze - wczesna epoka nowożytna), eds. W. IWAŃCZAK, S.K. KUCZYŃSKI, Warszawa 2001, pp. 419-428.

FĄKA M., "Synody arcybiskupa Henryka Kietlicza (1199-1219)", Prawo Kanoniczne 12 (1969), vol. 3-4, pp. 95-127.

FIJAŁEK, J., Życie i obyczaje kleru w Polsce średniowiecznej na tle ustawodawstwa synodalnego, Edition II, Kraków 2002, p. 32 [first printed as Średniowieczne ustawodawstwo synodalne biskupów polskich, part 1: Życie i obyczaje kleru w Polsce średniowiecznej na tle ustawodawstwa synodalnego, „Rozprawy Akademii Umiejętności, Wydział Historyczno-Filozoficzny”, series II, vol. V, Kraków 1894, pp. 181-239].

FLACHENECKER, H., Das beständige Bemühen und Reform. Zu Synoden und Synodalstatuten in den fränkichen Bistümern des 14./15. Jahrhunderts, [in:] Partikularsynoden im späten Mittelalter, hrsg. N. KRUPPA, L. ZYGNER, Göttingen 2006 [Veröffentlichungen des Max-Planck-Instituts für Geschichte, Band 219, Studien zur Germania Sacra Band 29].

GHIRLANDA, G., Wprowadzenie do prawa kościelnego, Kraków 1996.

HAMPEREK, P., GÓRALSKI, W., Historia źródeł nauki prawa kanonicznego, Lublin 1995.

HARTMANN W., Kirche und Kirchenrecht um 900. Die Bedeutung der spätkarolingischen Zeit für Tradition und Innovation im kirchlichen Recht, Hannover 2008.

HEATHER, P., Upadek cesarstwa rzymskiego, Poznań 2007.

Historia wychowania, ed. Ł. KURDYBACHA, vol. 1, Warszawa 1965.

KAŁWA, P., Rys historyczny prowincjonalnego ustawodawstwa synodalnego $w$ Polsce przedrozbiorowej, [in:] Ksiega pamiatkowa ku czci J.E.X. biskupa Mariana Leona Fulmana, part 1: Wydziały kościelne, Lublin 1939, pp. 126-155.

KARASIEWICZ, W., Jakub Świnka, arcybiskup gnieźnieński (1283-1314), Poznań 1948.

KARBOWIAK, A., "Szkoła katedralna kujawska w wiekach średnich", Kwartalnik Historyczny 12 (1898), pp. 763-777.

KIJEWSKA, A., Edukacja karolińska, [in:] Czasy katedr - czasy uniwersytetów. Źródła jedności narodów Europy, ed. W. SAJDEK, Lublin 2005, pp. 165-180.

KUMOR, B., Historia Kościoła, vol. 2: Wczesne średniowiecze chrześcijańskie, sec. edition., Lublin 2005.

KUMOR, B., Historia Kościoła, vol. 3: Zloty okres średniowiecza chrześcijańskiego, Lublin 2005.

LANDAU, P., Kanonistische Ergänzungen zur Germania und Bohemia Pontificia. Päpstliche Dekretalen an Emfänger im Reich zwischen 1140 und 1198, [in:] Sacri canones servandi sunt. Ius canonicum et status ecclesiae saeculis XIII-XV, ed. P. KRAFL, Praha 2008.

MIREWICZ, J. SJ, Wspóttwórcy i wychowawcy Europy, Kraków 1983.

MIŚKIEWICZ, M., Zarys kultury $i$ archeologii Europy $w$ okresie wczesnego średniowiecza, Warszawa 2002.

MUNDY, J.H., Europa średniowieczna 1150-1309, Warszawa 2001.

MYSZOR, W., Europa - pierwotne chrześcijaństwo. Idee i życie społeczne chrześcijan (II i III wiek), Warszawa 1999/2000.

NOWACKI, B., Arcybiskup Jakub Świnka - budziciel i propagator polskiej świadomości narodowej, [in:] 1000 lat archidiecezji gnieźnieńskiej, eds. J. STRZELCZYK, J. GÓRNY, Gniezno 2000, pp. 81-96.

PELCZAR, R., "Ustawodawstwo synodów diecezjalnych i listy pasterskie biskupów wobec szkolnictwa kościelnego dla świeckich w Polsce od XIII do XVIII wieku”, Archiwa, Biblioteki i Muzea Kościelne 67 (1997).

PIENIĄDZ-SKRZYPCZAK, A., Ad imitationem eius quaedam instituere providimus capitula... Działalność prawodawcza a ksztattowanie się wizerunku władcy $w$ księstwie Benewentu w VIII-IX wieku, [in:] Monarchia w średniowieczu. Władza nad ludźmi, władza nad terytorium. Studia ofiarowane Profesorowi Henrykowi Samsonowiczowi, eds. J. PYSIAK, A. PIENIĄDZ-SKRZYPEK, M.R. PAUK, Warszawa-Kraków 2002, pp. 73-96. 
POTKOWSKI, E., Moc księgi-przykład św. Bonifacego, [in:] Scriptura, custos, memoriae. Prace historyczne, ed. D. ZYDOREK, Poznań 2001, pp. 203-204.

RATAJCZAK, K., Edukacyjne aspekty ustawodawstwa Kościoła w Polsce średniowiecznej, [in:] Szkoła polska od średniowiecza do XX wieku między tradycja a innowacja, eds. I. SZYBIAK, A. FIJAŁKOWSKI, J. KAMIŃSKA, with collaboration of K. BUCZEK, Warszawa 2010, pp. 19-32.

RATAJCZAK, K., "Legaci apostolscy w wiekach średnich i ich rola w przyjmowaniu partykularnego ustawodawstwa kościelnego przez Kościół polski - aspekty edukacyjne", Biuletyn Historii Wychowania 26 (2010) [edition of 2011], pp. 7-17.

RATAJCZAK, K., Przyczyny powstania i rozwój sieci szkół kościelnych w średniowiecznej Wielkopolsce, [in:] Z dziejów polskiej kultury i oświaty od średniowiecza do początków XX wieku, eds. K. JAKUBIAK, T. MALISZEWSKI, Kraków 2010, pp. 165-180.

RATAJCZAK, K., "Ustawodawstwo szkolne soborów od XII do pierwszej połowy XIV w. i początki jego recepcji w średniowiecznej Polsce - zarys problemu”, Biuletyn Historii Wychowania 23 (2007), pp. 7-19.

RATAJCZAK, K., "XIII wiek - stulecie przełomu w dziejach średniowiecznego szkolnictwa w Polsce", Biuletyn Historii Wychowania 25 (2009), Poznań 2010, pp. 7-20.

RICHÉ, P., Edukacja i kultura w Europie Zachodniej (VI-VIII w.), Warszawa 1995.

SAWICKI, J., "Ze studiów nad synodami diecezji wrocławskiej w XIII wieku”, Prawo Kanoniczne 4 (1961), vol. 1, pp. 173-209.

SILNICKI, T., GOŁĄB, K., Arcybiskup Jakub Świnka i jego epoka, Warszawa 1956.

SIMON, M., Cywilizacja wczesnego chrześcijaństwa I-IV w., Warszawa 1979.

Stownik wczesnochrześcijańskiego piśmiennictwa, eds. J.M. SZYMUSIAK, M. STAROWIEJSKI SJ, Poznań 1971.

SMITH, J.M.H., Europa po Rzymie. Historia kulturowa lat 500-1000. Nowe ujęcie, Kraków 2008.

SUBERA, I., Synody prowincjonalne arcybiskupów gnieźnieńskich, Warszawa 1971.

SUBERA, I., Historia źródet i nauki prawa kanonicznego, Warszawa 1977.

TROCMÉ, É., Pierwsze kroki chrześcijaństwa, Kraków 2004.

Tymosz, S., Szkic historyczno-biograficzny prymasa Jana Łaskiego (1456-1531), [in:] Arcybiskup Jan Laski reformator prawa, ed. S. TYMOSZ, Lublin 2007.

ULANOWSKI, B., Kilka uwag o statutach synodów diecezjalnych krakowskich z XIV i XV wieku, Kraków 1888.

WALLACH, L., "Charlemagne's De litteris colendis and Alcuin”, Speculum 26 (1951), no. 2, pp. 288-305.

WŁODARSKI, S., Historia papiestwa, vol. 1: do 1073 r., Warszawa 1964.

WOOD, I., Kultura, [in:] Zarys historii Europy. Wczesne średniowiecze od 400 do 1000 r., ed. R. MC KITTERICK, Warszawa 2003.

ZYGNER, L., Drei polnische Bischöfe und Juristen Peter Wysz, Jakob aus Kurdwanów, Andreas Laskarii und ihre Synodaltätigkeit in den Diözesen Krakau, Płock und Posen, [in:] Partikularsynoden im späten Mittelalter, pp. 239-273. 
